\title{
First report of colonization by Panstrongylus megistus (Burmeister, 1835) (Hemiptera, Reduviidae, Triatominae) in the Metropolitan Region of São Paulo, Brazil
}

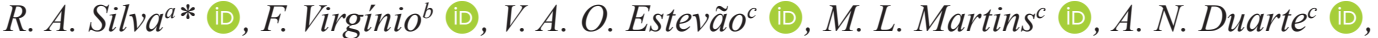

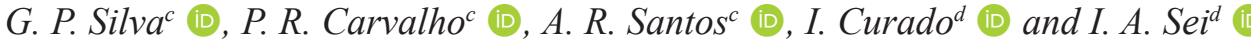

aLaboratório Especializado de Mogi Guaçu: Doença de Chagas, Diretoria de Combate a Vetores, Superintendência de Controle de Endemias, Rua Paula Sousa, 166, $1^{\circ}$ andar, Luz, CEP 01027-000, São Paulo, SP, Brasil

${ }^{\mathrm{b}}$ Grupo de Estudo em Entomologia Médica, Laboratório de Coleções Zoológicas, Instituto Butantan, Av. Vital Brazil, 1500, Butantã, CEP 05503-900, São Paulo, SP, Brasil

'Serviço Regional da Grande São Paulo, Superintendência de Controle de Endemias, Rua Cardeal Arcoverde, 2878, Pinheiros, CEP 05408-003, São Paulo, SP, Brasil

'Laboratório de Imunoepidemiologia, Superintendência de Controle de Endemias, Rua Paula Sousa, 166, $5^{\circ}$ andar, Luz, CEP 01027-000, São Paulo, SP, Brasil

*e-mail: rubensantoniosilva@gmail.com

Received: June 24, 2019 - Accepted: September 18, 2019 - Distributed: February 28, 2021

(With 2 figures)

\begin{abstract}
We report the first known occurrence of Panstrongylus megistus (Burmeister, 1835) (Hemiptera, Reduviidae, Triatominae) in the Metropolitan Region of São Paulo, Brazil. In 2018, adult specimens were sent by residents to the competent authorities and, in the inspection of the property, a large focus associated with a marsupial nest was found. This finding reinforces the importance of the species in the state of São Paulo, serves as an alert for epidemiological surveillance and extends the species colonization area in the state of São Paulo.
\end{abstract}

Keywords: Chagas disease, vector, triatomine, geographical distribution.

\section{Primeiro relato de colonização por Panstrongylus megistus (Burmeister, 1835) (Hemiptera, Reduviidae, Triatominae) na Região Metropolitana de São Paulo, Brasil}

\begin{abstract}
Resumo
Relatamos a primeira ocorrência de Panstrongylus megistus (Burmeister, 1835) (Hemiptera, Reduviidae, Triatominae) na Região Metropolitana de São Paulo, Brasil. Em 2018, espécimes adultos foram enviados por residentes e a pesquisa na propriedade constatou a presença de um grande foco associado a um ninho marsupial. Este achado reforça a importância da espécie no estado de São Paulo, serve de alerta para a vigilância epidemiológica e amplia a área de colonização da espécie no estado de São Paulo.
\end{abstract}

Palavras-chave: doença de Chagas, vetor, triatomíneo, distribuição geográfica.

\section{Introduction}

Chagas disease affects six to eight million people worldwide. It is considered endemic in Central and South America and has spread to other countries through the migration of people affected by the disease (Brasil, 2019).

The vectors of Chagas disease belong to the family Reduviidae and subfamily Triatominae, which has more than 153 species grouped into 18 genera, some of which are well adapted to habitations, which potentiates the vector transmission of Trypanosoma cruzi (Chagas, 1909), the etiological agent of this disease (Mendonça et al., 2016; Souza et al., 2016; Oliveira and Alevi, 2017).

In Brazil, field operational indicators have shown that the main vector species, Triatoma infestans (Klug, 1834), is restricted to small residual foci of little epidemiological importance in the northwest of the state of Rio Grande do Sul and in the western region of the state of Bahia, which led the Pan American Health Organization to provide Brazil with the International Certificate of Elimination 
of Chagas Disease Transmission for this species in June 2006 (PAHO, 2009).

However, to this day, transmission forms of epidemiological importance, such as vector, transfusion and transplacental transmission, as well as oral outbreaks, still expose individuals to risk of infection (Brasil, 2019). In endemic regions, wild foci remain, and invasion and colonization of the home and peridomiciliary areas by secondary vectors may cause the appearance of new cases of the disease (WHO, 2008; Brasil, 2019).

In the state of São Paulo, several triatomine species have already been reported, and the most collected were Triatoma sordida (Stal, 1859), Panstrongylus megistus (Burmeister, 1835), Rhodnius neglectus (Lent, 1954), and Triatoma tibiamaculata (Pinto, 1926) (Silva, 2019). The species that has the highest epidemiological importance is $P$. megistus, due to the high rates of infection by Trypanosoma cruzi and its proximity to humans, as it has been able to constitute colonies in intra and/or peridomiciles (Silva, 2019). In light of the importance of this species for public health, we report here, for the first time, colonization of the species P. megistus in the Metropolitan Region of São Paulo (MRSP).

\section{Material and Methods}

\subsection{Study area}

The Metropolitan Region of São Paulo comprises 39 municipalities. In November 2018, one resident reported four triatomines in his property. The region has areas of preserved forest and modified areas with fragments of the Atlantic forest, and there is good-quality housing in these spaces (EMPLASA, 2018).

\subsection{Notification}

The collaboration between the group of studies in medical entomology of the Special Laboratory of Zoological Collections of the Butantan Institute and SUCEN (Superintendence of Control of Endemias), a local authority of São Paulo's State Department of Health, was resumed in 2018. This collaboration consists of efforts related to reception of triatomines, taxonomic identification, diagnosis of triatomine infection, home inspections, and deposit of the specimens in the reference collection, according to the flow shown in Figure 1.

Four adult triatomines of the species $P$. megistus were received through the reception service of the Butantan Institute. Two of these insects were found in one of the rooms of the main residence that is used as an office and the other two in the bedroom. Of the four triatomines, two (one male and one female) were delivered to SUCEN, the agency responsible for vector control actions. The insects were deposited in SUCEN's zoological collection. The examination of intestinal contents for verification of trypanosomatid forms was carried out in the Specialized Laboratory of Mogi Guaçu: Chagas Disease.

When the presence of triatomines is notified, entomological research is carried out at the household to search for new specimens. This research is thorough in all insect shelter locations and in areas close to food sources. The response to the resident's notification occurred in a joint action with technicians and agents of the municipality and consisted in the inspection of the property, both in the inner and peridomiciliary areas. If new specimens are found, chemical control is performed with the use of pyrethroid insecticides, made available by the Brazilian Ministry of Health.

\subsection{Identification}

The identification of the species was based on the morphological characteristics described by Lent and Wygodzinsky (1979) and Galvão and Dale (2014).

\section{Results}

\subsection{New records}

The triatomines were found in the municipality of Carapicuíba, located in the MRSP (-23.562832, -46.863252), in November 2018, and were deposited in the zoological collection of the Specialized Laboratory of Mogi Guaçu: Chagas disease (voucher number LABEMGDC 97) (Figure 2).

In addition to the insects sent in the notification, when the field staff went to the property to perform the inspection, the residents delivered six other triatomines, of which five were adults (two males and three females) and one was a $5^{\text {th }}$ stage nymph. Two of the adult triatomines

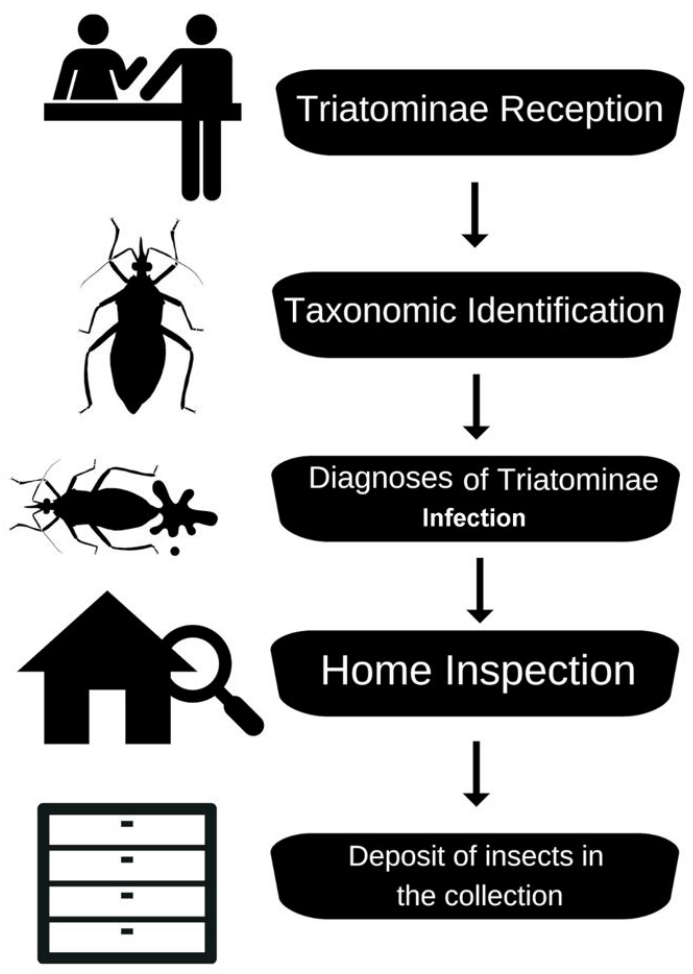

Figure 1. Flowchart of the work carried out by the Butantan Institute and SUCEN. 

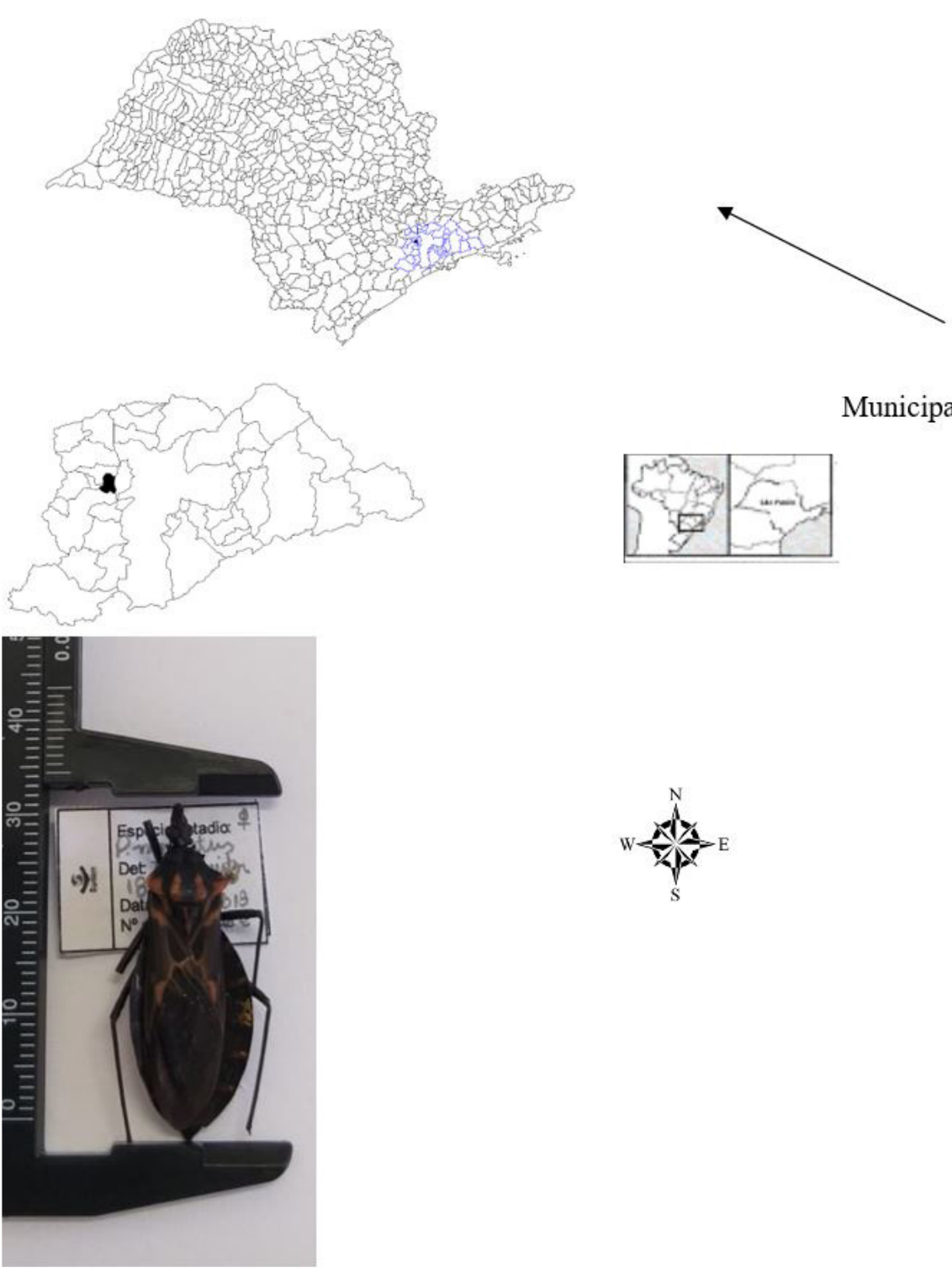

Municipality of Carapicuíba
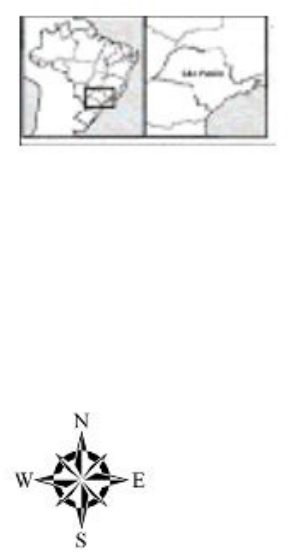

Figure 2. Specimen of Panstrongylus megistus collected in the Municipality of Carapicuíba and deposited in the entomological collection - triatomines of the Specialized Laboratory Mogi Guaçu: Chagas disease (voucher number LABEMGDC 97).

were found in the office and the other four insects in the notifier's bedroom.

The resident told the field staff about the presence of marsupials, popularly known as saruê (opossum), in the office's roof. Based on this information, it was possible to find a marsupial nest with seven other triatomines in different evolutionary stages (two $2^{\text {nd }}$ stage nymphs, two $3^{\text {rd }}$ stage nymphs and three $4^{\text {th }}$ stage nymphs). A new focus was found in the roof of another house in the property, in the opossum's nest, containing a collection of 39 specimens, mostly nymphs $(82.0 \%)$. All the collected insects were sent to the Specialized Laboratory of Mogi Guaçu: Chagas disease for colony formation and examination of intestinal contents, which proved negative for trypanosomatid forms.
Given the presence of a triatomine colony in the roof of one of the property's houses, a visit was scheduled for chemical treatment. Alpha-cypermethrin insecticide was used. Then, the municipal team provided orientation activities for the residents of dwellings situated within a 400 -meter radius of the notifying property.

\section{Discussion}

Chagas disease vector control in the state of São Paulo began in 1950 with activities aimed at combating Triatoma infestans, considered the main vector. Thanks to the efforts of SUCEN field teams, satisfactory results were obtained regarding the control of $T$. infestans in the home environment, 
culminating in the interruption of disease transmission in the early 1970s (Souza et al., 1984). Due to this, the wild triatomines, collected in the peridomicile, became more important in the state (Wanderley, 1993). In the MRSP, triatomine records were notifications of vector presence: the bugs, attracted by light, were found by residents and sent to SUCEN; field teams then inspected the properties, without finding new vectors.

Since 1970, the results of entomological surveys conducted to find triatomine species in MRSP houses have always been negative. In the period 2000-2019, the species P. megistus is the most important in the state of São Paulo, being notified by residents. It is worth mentioning that the surveillance strategy based on notification was responsible for triggering control actions and for the discovery of the first triatomine focus in the region. This reinforces the importance of a relationship of trust and communication between the population and the systems of surveillance and epidemiological control.

The species $P$. megistus is present in practically the entire Brazilian territory, except in the states of Amazonas, Amapá and Roraima (Gurgel-Gonçalves et al., 2012; Brasil, 2019). This vector is the most important in Brazil, due to its wide geographical distribution, high ability to colonize human environment and high indices of natural infection (Gurgel-Gonçalves et al., 2012).

Perlowagora-Szumlewicz et al. (1988) demonstrated the ability of parasitic multiplication in this vector. In addition, several authors have mentioned the relationship between the presence of white-eared opossums (Didelphis albiventris and Didelphis marsupialis) and T. cruzi infection, emphasizing the importance of these animals as a link between the wild and the human environments (Santos Junior et al., 2013; Lima et al., 2012; Steindel et al., 2008; Fernandes et al., 1991).

In São Paulo, P. megistus presents a restricted distribution range, in which its survival is favored by the rainfall regime, greater humidity and type of vegetation cover, being associated with marsupials of the Didelphidae family and rodents, resulting in a high rate of natural infection (Silva et al., 2014). This species can colonize the human environment and associate with dogs, cats, marsupials, rodents, cattle, goats and swine, among others, as has already been described in the case of T. cruzi infection (Carcavallo et al., 1997). The discovery of this focus associated with marsupial nests has put the MRSP on alert and corroborates the ecological valence already demonstrated for this species.

Deforestation and alterations in the natural environment can promote the displacement or disappearance of triatomines' natural refuges and food sources; as a result, they seek them in the alternative artificial environment for their survival. In these environments, food abundance allows the increase in the population of triatomines and can cause the resurgence of diseases considered controlled (Dias, 2000; Silveira, 2000).

As a strategy for action, the population must be oriented to notify the authorities of the presence of suspicious insects. This form of population participation, promoted in a continuous and long-lasting way, is an essential component of epidemiological surveillance, not only for the sustainability of the actions, but because surveillance with population participation is the most sensitive method of entomological research for triatomines. We believe that the work of environmental education and knowledge dissemination must be provided for the society, because, in the case of the present study, residents live in Atlantic forest reserves but, generally speaking, the population has never had experience with transmitters. In addition, in view of the species' dispersion (Forattini et al., 1977), the search for vectors in properties situated within a 400 -meter radius of the notifying dwelling should be implemented as a strategy, enabling the monitoring of the situation.

\section{References}

BRASIL. Ministério da Saúde. Secretaria de Vigilância em Saúde, 2019. Doença de Chagas aguda e distribuição espacial dos triatomíneos de importância epidemiológica, Brasil 2012 a 2016. Boletim Epidemiológico, vol. 50, pp. 1-10.

CARCAVALLO, R.U., ROCHA, D.S., GIRÓN, I., SHERLOCK, I.A., GALVÃO, C. and MARTINEZ, A., 1997. Fontes e padrões alimentares. In: R.U. CARCAVALLO, G.I. GIRÓN, J. JUBERG and H. LENT, eds. Atlas dos vetores da doença de Chagas nas Américas. Rio de Janeiro: Fiocruz.

DIAS, J.C.P., 2000. Epidemiologia. In: Z. BRENER, Z.A. ANDRADE and M. BARRAL NETTO, eds. Trypanosoma cruzi e Doença de Chagas. 2. ed. Rio de Janeiro: Guanabara Koogan, pp. 48-74.

EMPRESA PAULISTA DE PLANEJAMENTO METROPOLITANO S/A - EMPLASA, 2018 [viewed 26 May 2019]. Região Metropolitana de São Paulo [online]. Available from: https:// www.emplasa.sp.gov.br/RMSP

FERNANDES, A.J., CHIARI, E., RODRIGUES, R.R., DIAS, J.C. and ROMANHA, A.J., 1991. The importance of the opossum (Didelphis albiventris) as a reservoir for Trypanosoma cruzi in Bambuí, Minas Gerais State. Memórias do Instituto Oswaldo Cruz, vol. 86, no. 1, pp. 81-85. http://dx.doi.org/10.1590/S007402761991000100013. PMid:1842405.

FORATTINI, O.P., FERREIRA, O.A., SILVA, E.O.R. and RABELLO, E.X., 1977. Aspectos ecológicos da tripanossomíase americana. IX - Variação e mobilidade de Panstrongylus megistus em ecótopos artificiais. Revista de Saúde Pública, vol. 11, no. 2, pp. 199-213. http://dx.doi.org/10.1590/S0034-89101977000200005. PMid:410091.

GALVÃO, C. and DALE, C., 2014. Chaves de identificação para adultos. In: C. GALVÃO, ed. Vetores da doença de Chagas no Brasil. Curitiba: Sociedade Brasileira de Zoologia, vol. 1, pp. 171-208. http://dx.doi.org/10.7476/9788598203096.0009.

GURGEL-GONÇALVES, R., GALVÃO, C., COSTA, J. and PETERSON, A.T., 2012. Geographic distribution of Chagas disease vectors in Brazil based on ecological niche modeling. Journal of Tropical Medicine, vol. 2012, pp. 1-15. http://dx.doi. org/10.1155/2012/705326. PMid:22523500.

LENT, H. and WYGODZINSKY, P., 1979. Revision of the Triatominae (Hemiptera Reduviidae), and their significance as vectors of Chagas' disease. Bulletin of the American Museum of Natural History, vol. 163, pp. 123-520. 
LIMA, M.M., SARQUIS, O., OLIVEIRA, T.G., GOMES, T.F., COUTINHO, C., DAFLON-TEIXEIRA, N.F., TOMA, H.K., BRITTO, C., TEIXEIRA, B.R., D'Andrea, P.S., JANSEN, A.M., BÓIA, M.N. and CARVALHO-COSTA, F.A., 2012. Investigation of Chagas disease in four periurban areas in northeastern Brazil: epidemiologic survey in man, vectors, non-human hosts and reservoirs. Transactions of the Royal Society of Tropical Medicine and Hygiene, vol. 106, no. 3, pp. 143-149. http://dx.doi. org/10.1016/j.trstmh.2011.10.013. PMid:22136953.

MENDONÇA, V.J., ALEVI, C., PINOTTI, H., GURGELGONÇALVES, R., PITA, S., GUERRA, A.L., PANZERA, F., DE ARAÚJO, R.F., AZEREDO-OLIVEIR, M.T. and ROSA, J.A., 2016. Revalidation of Triatoma bahiensis Sherlock \& Serafim, 1967 (Hemiptera:Reduviidae) and phylogeny of the T. brasiliensis. Zootaxa, vol. 4107, no. 2, pp. 239-254. http://dx.doi.org/10.11646/ zootaxa.4107.2.6. PMid:27394816.

OLIVEIRA, J. and ALEVI, K.C.C., 2017. Taxonomic status of Panstrongylus herreri Wygodzinsky,1948 and the number of Chagas disease vectors. Brazil. Revista da Sociedade Brasileira de Medicina Tropical, vol. 50, no. 3, pp. 434-435. http://dx.doi. org/10.1590/0037-8682-0125-2017. PMid:28700072.

PANAMERICAN HEALTH ORGANIZATION - PAHO, 2009 [viewed 18 June 2018]. Chagas disease [online]. Washington. Available from: https://www.paho.org/hq/index.php?option=com_content\&view=a rticle \&id $=2180 \% 3$ A2009-chagas-disease $\&$ catid $=1719 \% 3$ Apcpcdecuador2\&Itemid=1873\&lang=en

PERLOWAGORA-SZUMLEWICZ, A., MÜLLER, C.A. and MOREIRA, C.J.C., 1988. Studies in search of a suitable experimental insect model for xenodiagnosis of hosts with Chagas' disease. 3 - On the interaction of vectors species and parasite strain in the reaction of bugs to infection by Trypanosoma cruzi. Revista de Saúde Pública, vol. 22, no. 5, pp. 390-400. http:// dx.doi.org/10.1590/S0034-89101988000500004. PMid:3150613.

SANTOS JUNIOR, J.E., VIOLA, M.G., LOROSA, E.S., MACHADO, E.M., RUAS-NETO, A.L. and CORSEUIL, E., 2013. Evaluation of natural foci of Panstrongylus megistus in a forest fragment in Porto Alegre, State of Rio Grande do Sul, Brazil. Revista da Sociedade Brasileira de Medicina Tropical, vol. 46, no. 5, pp. 575-583. http://dx.doi.org/10.1590/0037-86820149-2013. PMid:24270248.
SILVA, R.A., 2019. Estado atual da vigilância entomológica da doença de Chagas no estado de São Paulo. Brazilian Journal of Health Review, vol. 2, pp. 742-755.

SILVA, R.A., BARBOSA, G.L. and RODRIGUES, V.L.C.C., 2014. Vigilância epidemiológica da doença de Chagas no estado de São Paulo no período de 2010 a 2012. Epidemiologia e Serviços de Saúde: Revista do Sistema Único de Saúde do Brasil, vol. 23, no. 2, pp. 259-267. http://dx.doi.org/10.5123/ S1679-49742014000200007.

SILVEIRA, A.C., 2000. Situação do controle da transmissão vetorial da doença de Chagas nas Américas. Cadernos de Saúde Pública, vol. 16, suppl. 2, pp. 35-42. http://dx.doi.org/10.1590/ S0102-311X2000000800004. PMid:11119318.

SOUZA, A.G., VALÉRIO-WANDERLEY, D.M., BURALLI, G.M. and ANDRADE, J.C.R., 1984. Consolidation of the control of Chagas' disease vectors in the state of São Paulo. Memórias do Instituto Oswaldo Cruz, vol. 79, suppl., pp. 125-132. http:// dx.doi.org/10.1590/S0074-02761984000500023.

SOUZA, E.D., VON ATZINGEN, N.C., FURTADO, M.B., OLIVEIRA, J., NASCIMENTO, J.D., VENDRAMI, D.P., GARDIM, S. and ROSA, J.A., 2016. Description of Rhodnius marabaensis sp. n. (Hemiptera,Reduviidade, Triatominae) from Pará State, Brazil. ZooKeys, vol. 62, no. 621, pp. 45-62. PMid:27833419.

STEINDEL, M., KRAMER PACHECO, L., SCHOLL, D., SOARES, M., MORAES, M.H., EGER, I., KOSMANN, C., SINCERO, T.C.M., STOCO, P.H., MURTA, S.M.F., CARVALHOPINTO, C.J. and GRISARD, E.C., 2008. Characterization of Trypanosoma cruzi isolated from human, vectors and animals reservoirs following outbreak of acute human Chagas disease in Santa Catarina State, Brazil. Diagnostical Microbiologic Infective Disease, vol. 60, no. 1, pp. 25-32. http://dx.doi.org/10.1016/j. diagmicrobio.2007.07.016. PMid:17889480.

WANDERLEY, D.M.V., 1993. Controle do Triatoma infestans no Estado de São Paulo. Revista da Sociedade Brasileira de Medicina Tropical, vol. 26, suppl. 3, pp. 17-25. PMid:7855355.

WORLD HEALTH ORGANIZATION - WHO, 2008. Chagas disease: control and elimination. Geneva. Report of the Secretariat EB124/17. 